11. Gallagher M., Whitehouse M.J., Kamber B.S. 2017. The Neoarchaean surficial sulphur cycle: An alternative hypothesis based on analogies with 20th century atmospheric lead. Geobiology. 15(3). P. 385-400.

12. Hartmann L. A., Provenance and age delimitation of Quadrilátero Ferrífero sandstones based on zircon U-Pb isotopes. J. of South Am. Earth Sci. 20. P. 273-285 (2006).

13. Holland H.D., 2009. Why the atmosphere became oxygenated: a proposal. Geochimica et Cosmochimica Acta. 73(18). P. 5241-5255.

14. Jamieson J.W., Wing B.A., Farquhar J. et al. 2013. Neoarchaean seawater sulphate concentrations from sulphur isotopes in massive sulphide ore. Nature Geoscience. 6(1). P. 61.

15. Kasting J.F. 2001. The rise of atmospheric oxygen. Science. 293(5531). P. 819-820.

16. Moore T.S., Murray R.W., Kurtz A.C. et al. 2004. Anaerobic methane oxidation and the formation of dolomite. Earth and Planetary Science Letters. 229(1). P. 141-154.

17. Paris G., Adkins J.F., Sessions A.L. et al. 2014. Neoarchean carbonateassociated sulfate records positive $\Delta 33 \mathrm{~S}$ anomalies. Science. 346(6210). P. 739-741. 18. Pavlov A.A., Kasting J.F. 2002. Mass-independent fractionation of sulfur isotopes in Archean sediments: strong evidence for an anoxic Archean atmosphere. Astrobiology. 2(1). P. 27-41.

19. Zhelezinskaia I., Kaufman A.J., Farquhar J. et al. 2014. Large sulfur isotope fractionations associated with Neoarchean microbial sulfate reduction. Science. 346(6210). P. 742-744.

\title{
СТАТИСТИЧЕСКИЙ АНАЛИЗ СОСТАВОВ ИНДИКАТОРНЫХ МИНЕРАЛОВ КИМБЕРЛИТОВ
}

Иванов А.С.

https://doi.org/10.31241/MIEN.2018.14.20

IvanovAS@alrosa.ru

Для статистической обработки применяют химические (микрозондовые) составы представительных выборок индикаторных минералов кимберлитов (ИМК). К таким минералам относятся: пиропы, пикроильмениты, хромиты, оливины, пироксены из известных кимберлитовых трубок и их ореолов.

В основе статистического анализа лежит сочетание методов анализа данных (R и $\mathrm{G}$ методы кластерного анализа) и многомерных статистических методов (факторный анализ). Проба минералов представляет после статистического анализа в таблице ряд средних частот встречаемости составов выделенных кластерных групп гранатов, пикроильменитов, хромшпинелидов, оливинов или пироксенов (рис. 1). А их групповая кластерная сходи- 
мость (больших и малых кластерных расстояний) дополняется и парной вероятностной оценкой - коэффициентом Пирсона.

Установление высокой значимой корреляции, частот встречаемости отдельных кластерных групп составов минералов-спутников алмазов, с продуктивностью кимберлитовых тел на алмазы и их физическими свойствами позволяет направить поиски на обнаружение алмазоносных кимберлитовых месторождений алмазов $\{2\}$.

Для поисковой геологии статистическая обработка составов ИМК кимберлитовых трубок имеет целый ряд прикладных значений:

1. Одно из прикладных направлений это выделение и картирование генетической совокупности кустов кимберлитовых трубок и их полей.

2. Второе и более важное прикладное значение - определение вероятностной принадлежности неизвестных проб из ореолов ИМК к выявленным месторождениям.

3. Третье направление - выяснение их генетической принадлежности к структурным элементам территории и алмазоносным кимберлитовым источникам.

4. Статистический анализ составов ИМК позволяет также вычислить, какие минералы росли вместе в мантии на глубине более сотен километров.

Для разделения составов пиропов на когерентные группы автор предлагает использовать кластерный анализ k-среднего. Алгоритм данного вида разделения (k-среднего) не позволяет соотнести в однородные группы содержания элементов разных числовых порядков. Чтобы не допускать такие ошибки, предложено последовательное - разделение больших значений составов методом (k-среднего), а затем малых долей процентов этим же методом в кластерных группах первого порядка. В итоге получаем однородные группы составов пиропов с нормальным законом распределения по всем девяти переменным ( $\left.\mathrm{SiO}_{2}, \mathrm{Al}_{2} \mathrm{O}_{3}, \mathrm{MgO}, \mathrm{CaO}, \mathrm{TiO}_{2}, \mathrm{Cr}_{2} \mathrm{O}_{3}, \mathrm{MnO}, \mathrm{FeO}, \mathrm{Na}_{2} \mathrm{O}\right)$. Перечисленные элементы являются основными минералообразующими элементами ИМК.

Перед началом статистического анализа составов ИМК по каждой группе минералов избавляют от «ураганных» значений, затем сортируют на представительное количество кластерных групп. В современных условиях развития компьютерных технологий сортировка составов ИМК (индикаторных минералов кимберлитов) на кластерные группы может выполняться при помощи любой статистической программы. Сущность статистического анализа (k- среднего) основана на том, что дисперсии всех измеренных химических элементов разделяются на одинаковое количество рангов ( $\mathrm{n}^{*} . .$. кластеров), и выборки n-кратным подбором выбираются и сортируются в кластерные группы. Алгоритм анализа можно выразить формулой $\{(\mathrm{Xcp}-\mathrm{Xi})=\mathrm{R}\}$, где $\mathrm{R}$ определяет дисперсионный ранг и количество кластерных групп.

Номинальный порядок кластерных групп при кластерном анализе соответствует порядку алгоритма, он произвольный, и поэтому его необходимо 
устанавливать по химическим особенностям минералов или при большом количестве кластерных групп интегрировать групповым кластерным анализом колонки - частот встречаемости кластерных групп (ЧВКГ) в большие и малые ветви кластерных расстояний. Ниже продемонстрирован (рис. 1) статистический анализ составов пиропов ультраосновных ЧВКГ из ореолов и кимберлитовых трубок мирнинского района.

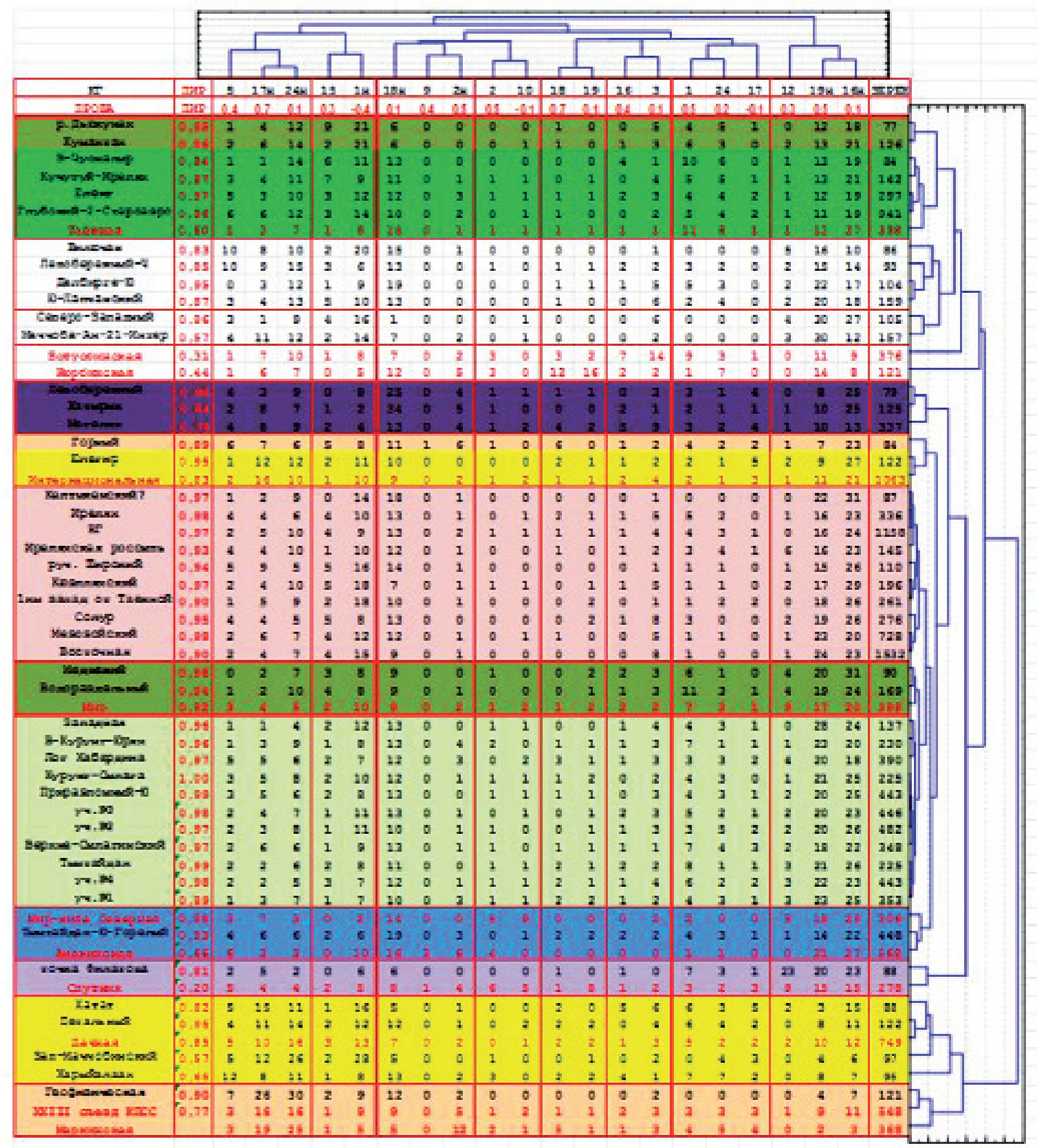

Рис. 1. Кластерный анализ ЧВКГ ультраосновных составов пиропов мирнинского района.

Составы пиропов по строчкам групповым кластерным анализом объединяют в малые и большие кластерные группы, близость сходимости по рядам ЧВКГ вычисляем коэффициентом Пирсона, который при переводе в проценты и определят и вероятность парной близости проб между собой. 
Факторный анализ дополняет кластерный анализ факторной (вероятностной) значимостью, по которой производится сортировка выборок составов ИМК по их различию и сходимостью рядов частот встречаемости кластерных групп. Таким образом, факторный анализ сортирует выборки составов ИМК по их корреляционной близости (рис. 2).
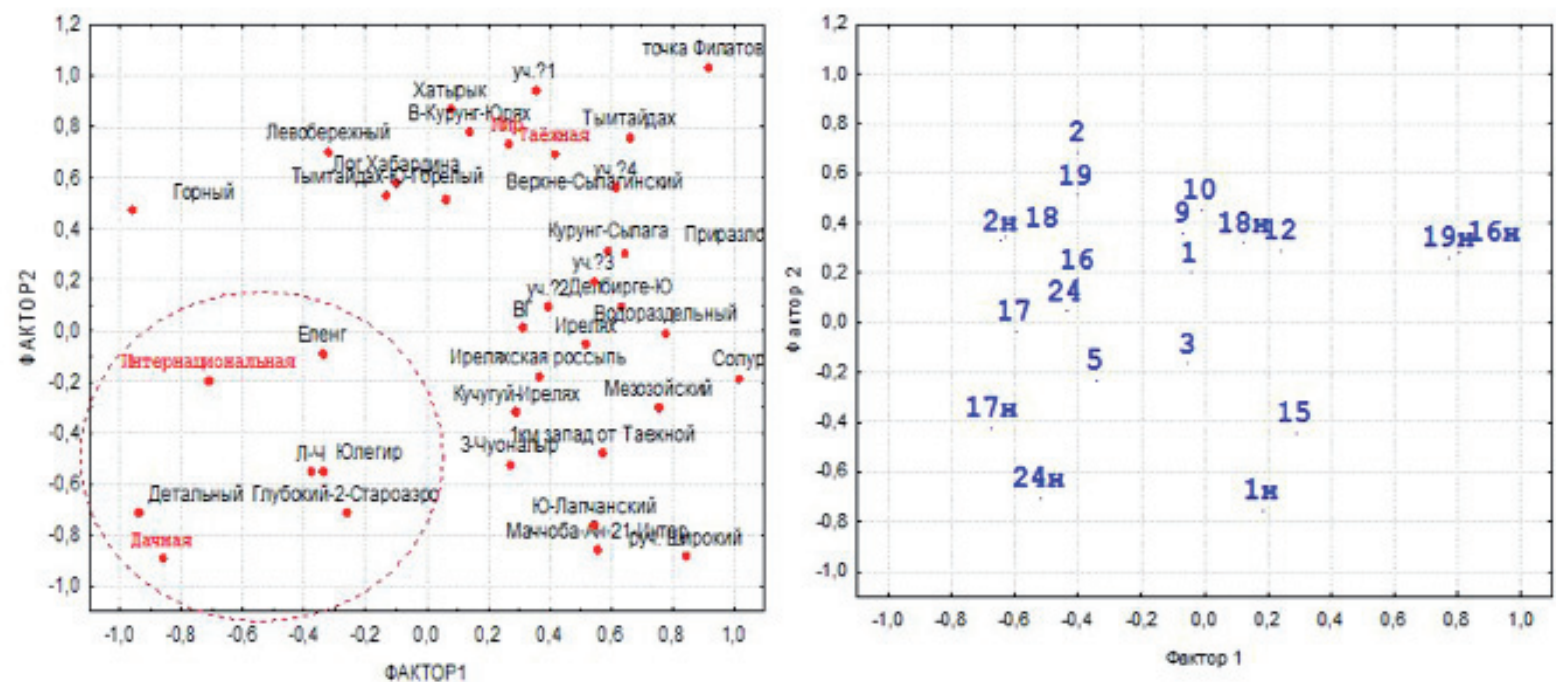

Рис. 2. Проекции на оси главных факторов ЧВКГ составов пиропов из проб ореолов и трубок мирнинского кимберлитового поля. Справа синхронная диаграмма их характеризующих факторов - принщипиальных компонент.

Ниже на диаграммах Н.В. Соболева показаны номера средне кластерных областей составов пиропов мирнинского кимберлитового поля (рис. 3 a, б) и составы пиропов в кластерных областях ультраосновных парагенезисов с крестиками средне кластерных их значений.
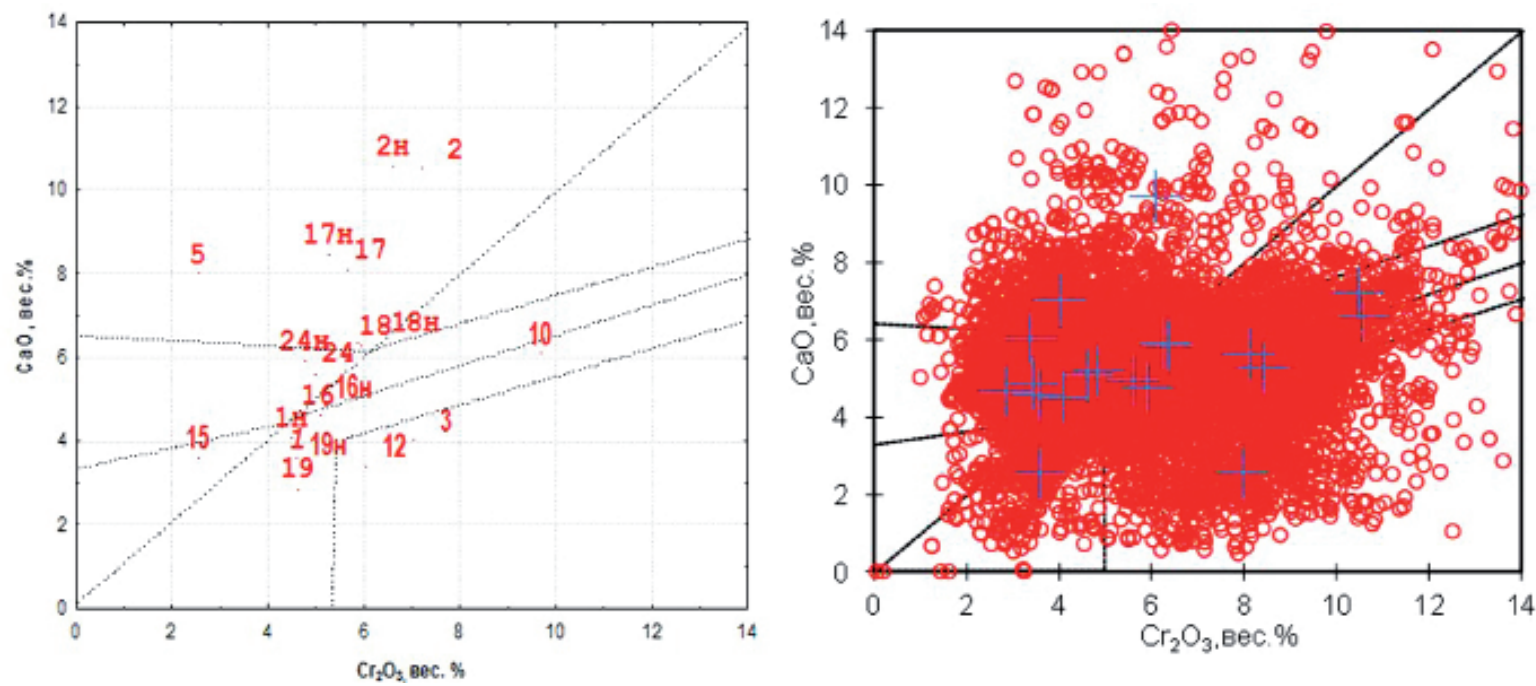

Рис. 3 а, б. Диаграммы Н.В. Соболева для средне кластерных областей значений ЧВКГ составов пиропов ультраосновного парагенезиса мирнинского кимберлитового поля - слева и справа эти области крестиками плюс фигуративнье точки составов кружочками. 
Средне кластерные элементные значения КГ ИМК целесообразно пересчитывать на химико-генетические группы профессора В.К. Гаранина (МГУ), кластерные группы Dawson J.B., на парагенетические группы Н.В. Соболева и другие известные классификационные составы. Гистограммы ЧВКГ составов ИМК воспринимаются гораздо проще, чем диаграммы факторного и кластерного анализа. Для простоты восприятия и наглядности статистического анализа демонстрировать лучше гистограммы ЧВКГ составов ИМК (рис. 4 а, б).
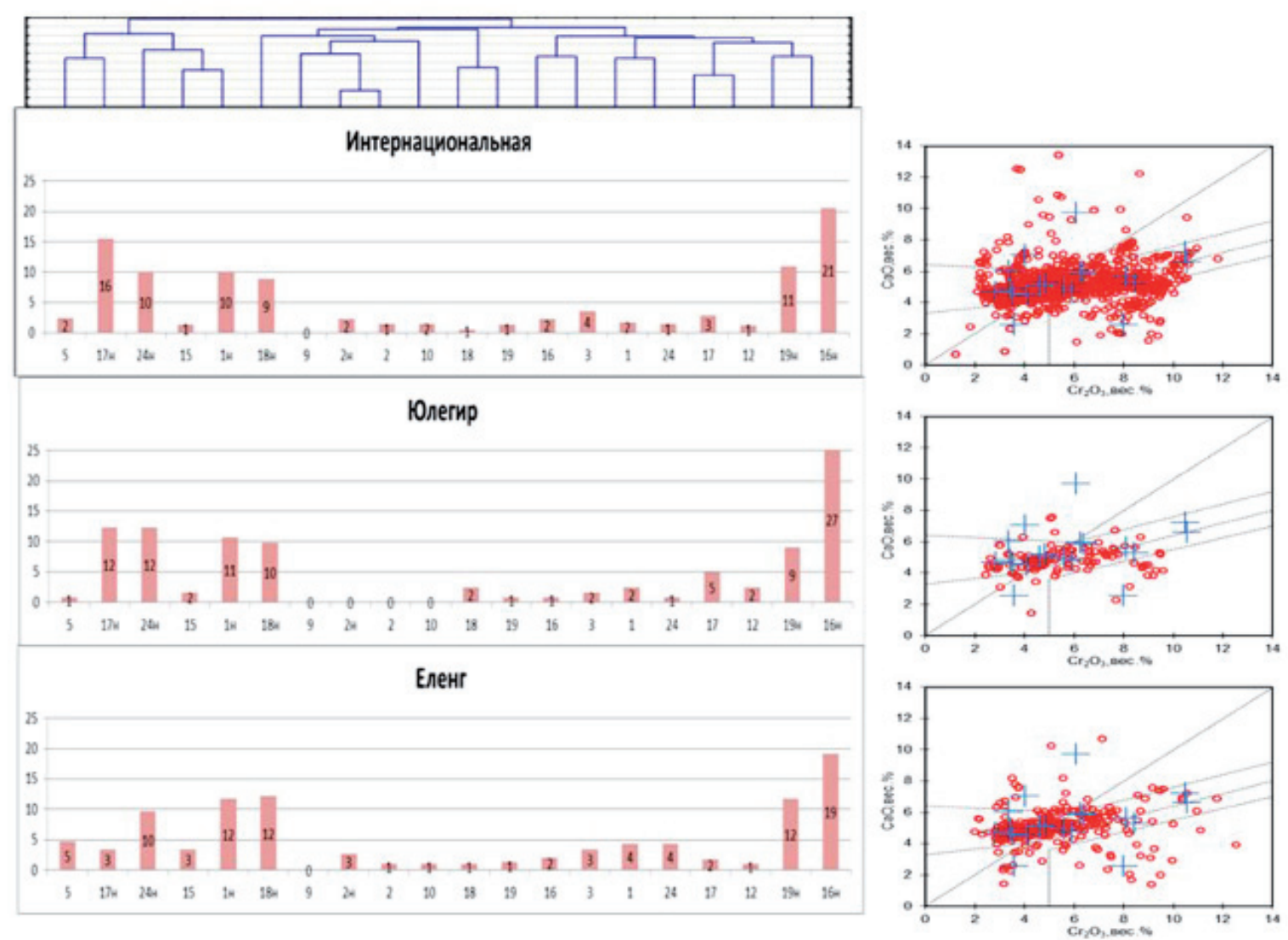

Рис. 4 а,б. Гистограммы ЧВКГ составов пиропов ультраосновных парагенезисов (а) и диаграммь Н.В. Соболева для ореолов и кимберлитовой трубки Интернациональная.

Можно вычислить и корреляцию между колонками ЧВКГ и строчками (пробами). При положительной корреляции между колонками ЧВКГ по точкам средне кластерных значений составов ИМК целесообразно установить тренды изменения составов ИМК на диаграммах их составов - это и будут парагенетические тренды изменения составов ИМК, которые зависят от состава расплава и от изменения его РТ параметров кристаллизации (рис. 5,6 ).

Находки в кимберлитовых породах неизмененных мантийных пород (мантийных ксенолитов) редки, но они как раз и несут основную информацию о совместной кристаллизации породообразующих и акцессорных минералов (минеральном парагенезисе). Если эти мантийные ксенолиты содер- 

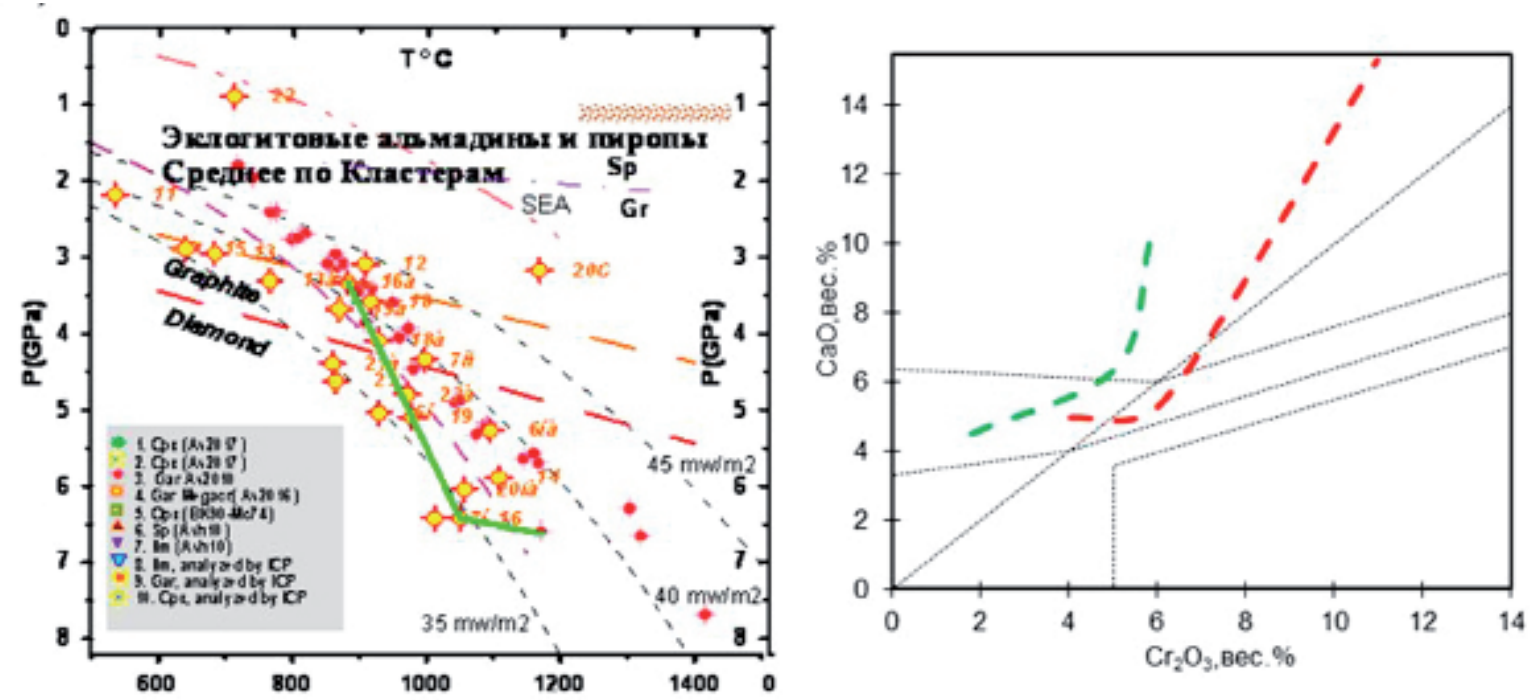

Рис. 5, 6. Тренды РТ параметров кристаллизачии пиропов с синхроннылм изменением состава с низкими и высокими их значениями по содержанию хрома, кальция и магния при сохранении парагенетических условий совместного образования алмазов на диаграммах И.В. Ащеепкова - слева и Н.В. Соболева.

жат также алмазы, то эти парагенезисы называют алмазоносными. В кимберлите неизмененные мантийные ксенолиты встречаются довольно редко. Чаще в кимберлитовых трубках находят мантийные ксенолиты эклогитовых парагенезисов, которые более стойкие к процессам выветривания, чем мантийные ксенолиты перидотитовых разностей. На основании находок мантийных ксенолитов с алмазами и без алмазов разработаны классификации ксенолитов - алмазоносных и неалмазоносных.

Определить какие минералы росли вместе на глубине более сотни километров с алмазами или без алмазов, можно и математическим путем, привлекая статистический анализ базы данных минералов из кимберлитов $\{5\}$. Для этого необходимо определить химические составы основных кимберлитовых минералов из представительного числа образцов. К таким минералам необходимо относить породообразующие и акцессорные минералы: пироксены, оливины, пиропы, пикроильмениты, хромшпинелиды. Затем следует разбить на кластерные группы каждый минеральный вид (породообразующие и акцессорные), определить среднее кластерное значение и частоты встречаемости кластерных групп в различных кимберлитовых разновидностях (пробах). Далее методами групповой и парной корреляцией между частотами встречаемости кластерных групп объединить группы минералов с наибольшими корреляционными положительными соотношениями. Таким образом, можно вычислить парастерезис (совместное обнаружение) ряда акцессорных минералов пиропов, хромшпинелидов и пикроильменитов с определенными формами алмазов и их цветами фотолюминесценции для основных кимберлитовых полей. Результатом статистического анализа есть возможность установить высокую значимую положительную корреляцию для частот встречаемости определенных кластерных групп составов 
пироксенов и кластерных групп составов пиропов. В кимберлитовых трубках Анголы были определены частоты встречаемости групп составов пиропов и хромистых диопсидов, между частотами встречаемости в трех парах вычислена высокая положительная корреляция (табл. 1, рис. 7), также построены графики частот встречаемости во всех трех парах минеральных парастерезисов.

Таблица 1. Частоты встречаемости трех пар вычисленных минеральных парастерезисов пироксенов и пиропов (в отн. \% от выборок зерен) из ряда кимберлитовых трубок Анголы с их парной корреляцией между их встречаемостью.
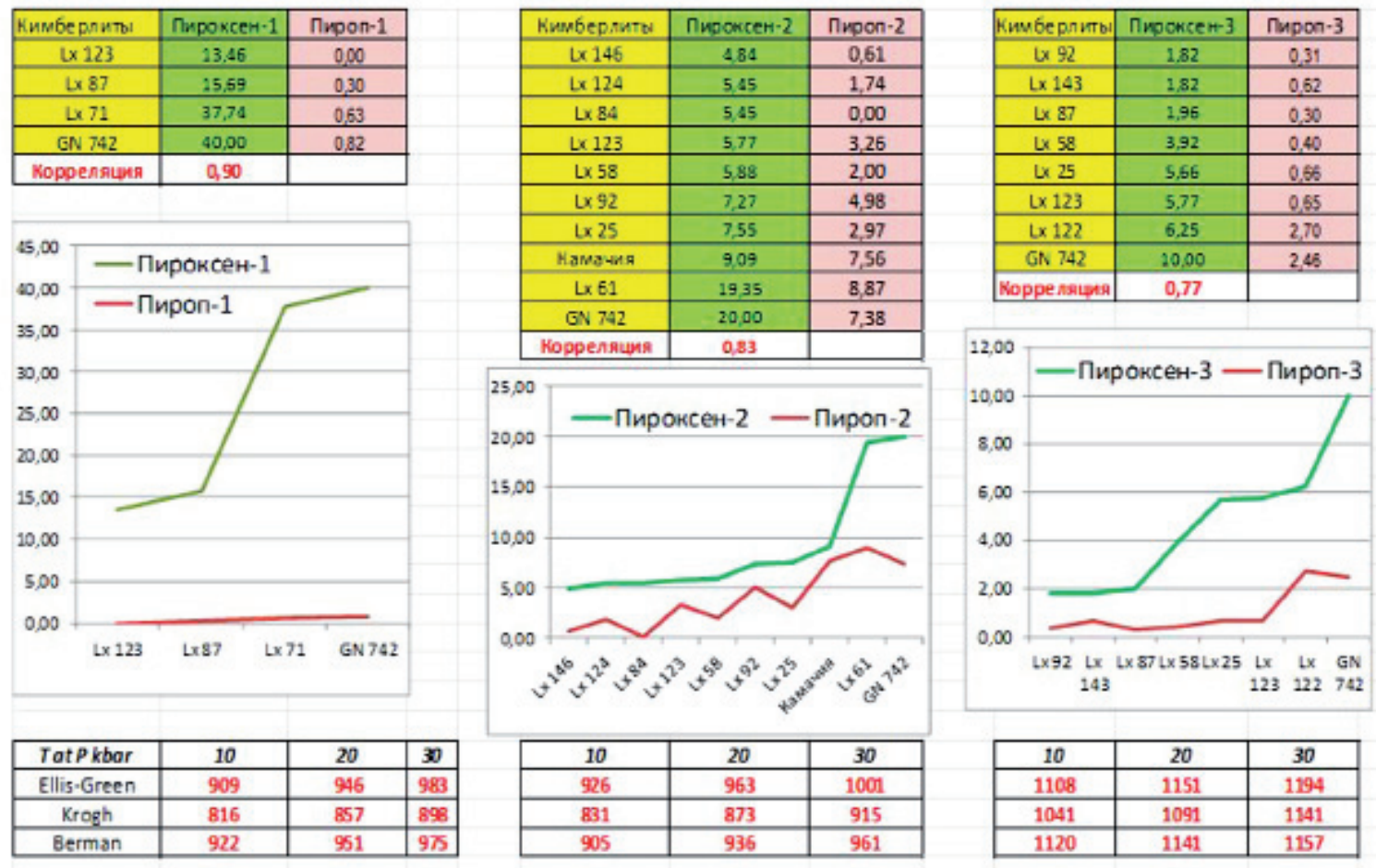

Рис. 7. Диаграммы частот встречаемости трех пар минеральных парастерезисов (пироксен-пироп) в представительных пробах из кимберлитовых трубок $А$ гольл. Внизу рисунка приведены таблички с расчетами РТ параметров кристаллизачии определенных трех пар парастерезисов пироксенов и пиропов по алгоритмам трех зарубежным авторов.

Имеют прикладное значение для поисковой геологии и результаты статистической обработки ЧВКГ составов пиропов (G1-G24), пикроильменитов (P1-P16), габитусных форм кристаллов алмазов (ЛРД, ОРД - линейные и округлые ромбододекаэдры), групп фотолюминесценции алмазов и продуктивности (АЛМАЗ - карат на тонну) кимберлитовых тел мирнинского кимберлитового поля $\{2\}$. Ниже приведена диаграмма главных факторов ЧВКГ и габитусных форм кристаллов алмазов, групп фотолюминесценции алмазов и продуктивности кимберлитовых тел мирнинского кимберлитового поля (рис. 8). 


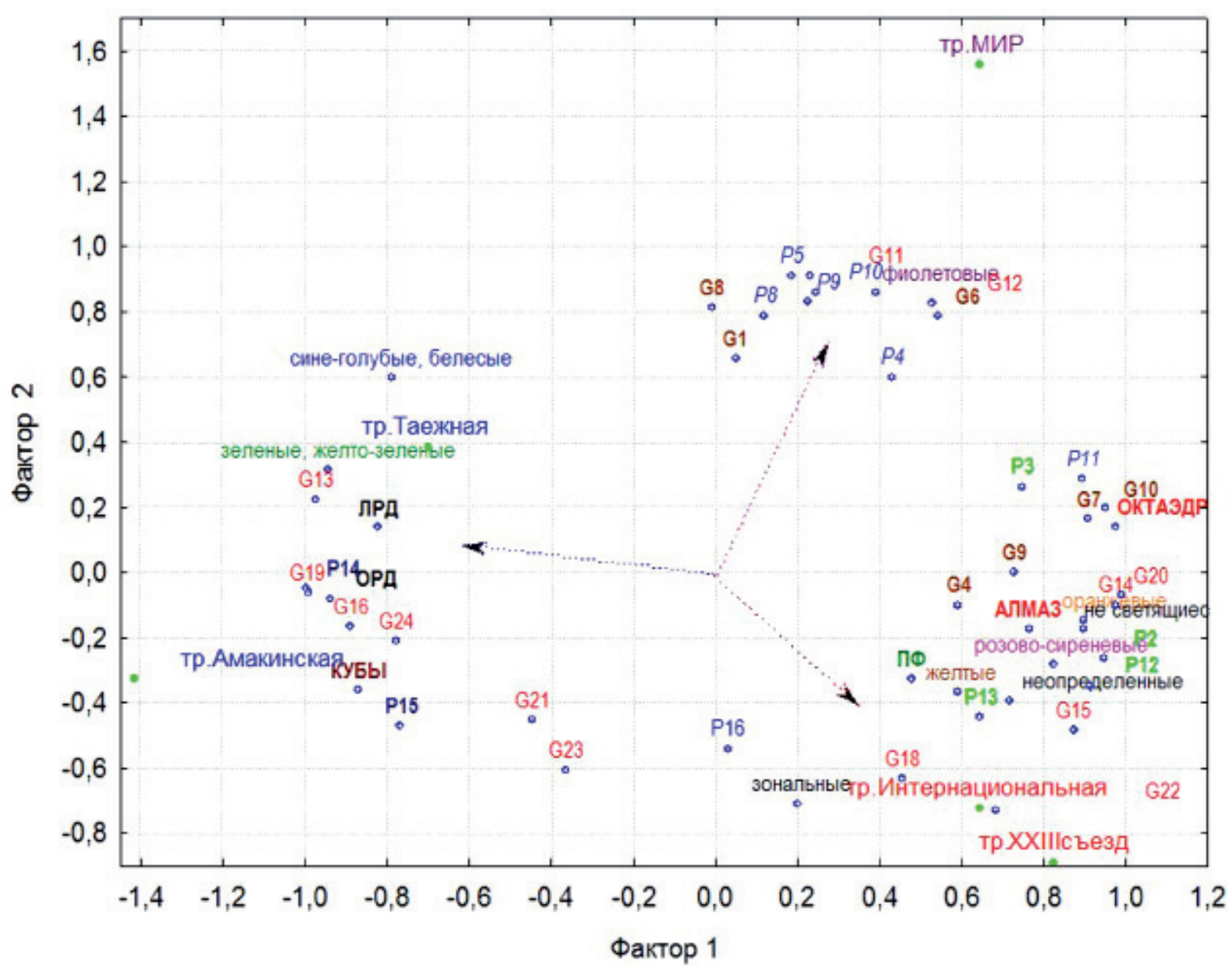

Рис. 8. Диаграмма главных факторов ЧВКГ ИМК и и габитусных форм кристаллов алмазов, групп фотолюминесиенции алмазов и продуктивности кимберлитовых тел мирнинского кимберлитового поля.

Для кластерных рангов соотношений составов пиропов, через точки проб с близкими частотами встречаемости их составов, существует возможность провести их структурные контролирующие линии $\{4\}$ (рис. 9, 10).

На картах Алакит-Мархинского поля (рис. 9, 10) программой построения изолиний показана зональность ЧВКГ. Зональность контролируется тектоникой. В областях низких ранговых соотношений ЧВКГ преобладают интенсивные внедрение кимберлитов, которые обогащены эклогитами. В областях высоких ранговых соотношений ЧВКГ преобладают ультраосновные породы. Промышленно алмазоносные кимберлиты располагаются в самых узких местах их совместных выбросов, где изолинии сближаются до максимума. Аналогичные построения, выполненные по сети поисковых проб, указывают направление на локальную область в ореоле ИМК, перспективу на возможное выявление алмазоносных кимберлитовых трубок.

\section{Список литературы}

1. Дж. Дж. Герни, Р. О. Мур. Геохимическая корреляция между минералами кимберлитов и алмазами Кратона Калахари, Журнал. Геология и Геофизика. Москва. 1994. С. 12-24. 


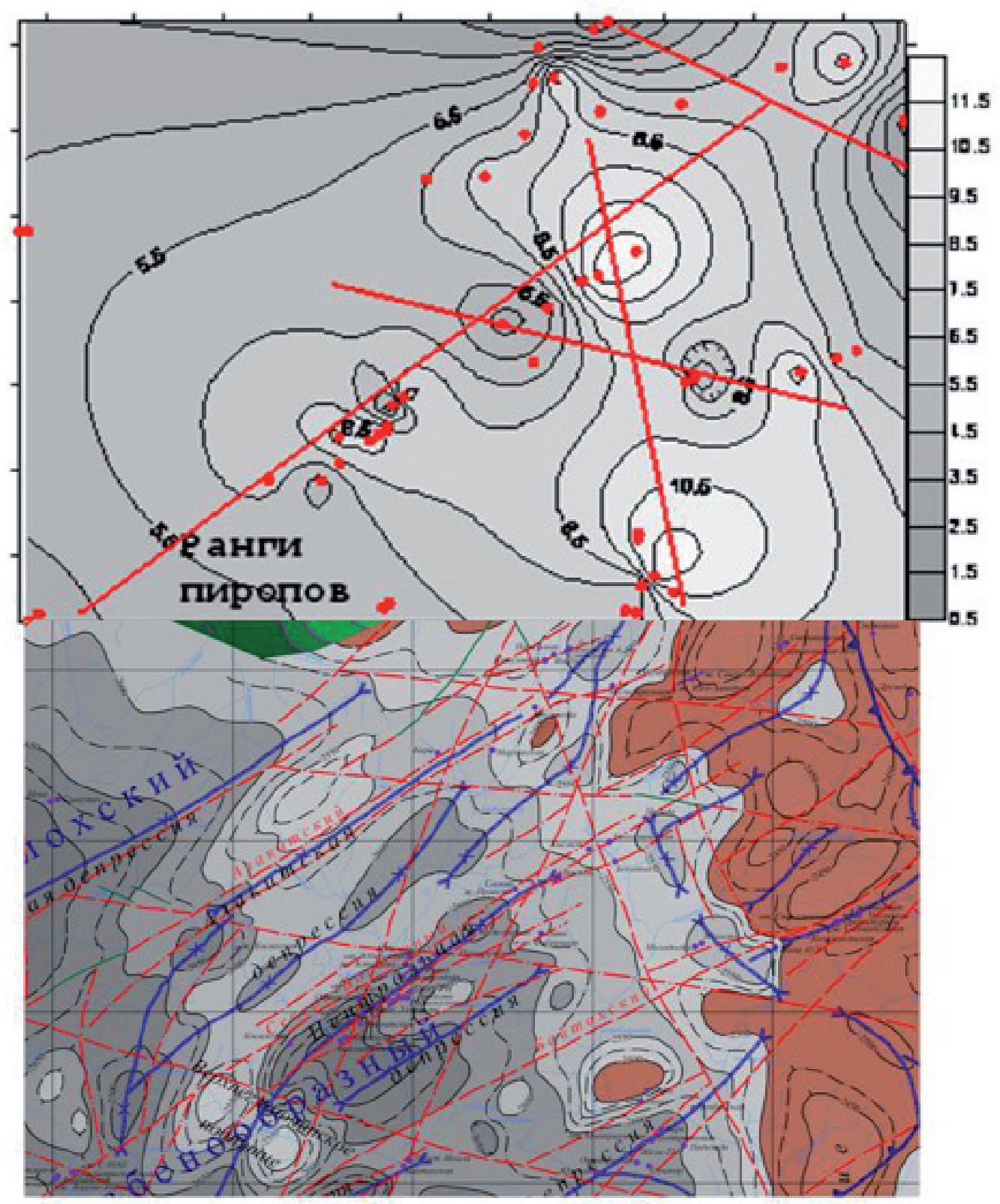

Рис. 9, 10. Карта одинаковых кластерных соотношений встречаемости кластерных групп пиропов Алакит-Мархинского кимберлитового поля (красными точками обозначены кимберлитовые трубки, линии через одинаковые значения кластерных рангов являются контролирующими тектонику) - вверху и внизу тектоническая карта этого же района.

2. Иванов А.С., Помазанский Б.В. О зависимости между частотами встречаемости кластерных групп составов МСА (пироп, пикроильменит), габитусных форм, цвета фотолюминесценции алмазов, продуктивности кимберлитов на МСА и алмазы. Труды XIII Всероссийской (с международным участием) Ферсмановской сессии. КНЦ РАН г. Апатиты, 2016. С. 169-181. 3. Иванов А.С. Новый критерий алмазоносности кимберлитов. Труды XII Всероссийской (с международным участием) Ферсмановской сессии. КНЦ РАН г. Апатиты, 2015. С. 268-270. 
4. Иванов А.С. Методика статистической обработки составов типоморфных минералов кимберлитовых трубок в Якутии. Прикладная Геохимия. Вып. 5. Москва. 2005.

5. Иванов А.С. Методика вычисления минеральных парастерезисов в кимберлитах. Труды XIII Всероссийской (с международным участием) научной школы «Математические исследования в естественных науках». КНЦ РАН Апатиты, 2016.С. 147-151.

6. Иванов А.С. Статистическое сравнение составов минералов-спутников алмазов на разных уровнях вероятности и его прогнозно-поисковое значение // Вопросы методики прогнозирования и поисков месторождений полезных ископаемых. ЯНИГП ЦНИГРИ АК «АЛРОСА». 2004. С. 247-253.

7. Квасница В.Н., Мацюк С.С., Вуйко В.И. О парагенетической связи алмаз - гранат // Минералогический журнал. 1984. № 5. С. 23-34.

8. Соболев Н.В. О минералогических критериях алмазоносности кимберлитов // Геология и геофизика 1971. №3. С. 70-80.

9. Dawson J.B., Stephens W.E. Statistical classification of garnets from kimberlites and xenoliths. J. Geol. 1975. V. 83. № 5. P. 589-607.

\section{ВОЛНОВАЯ ГЕОДИНАМИКА И ПЛОЩАДНЫЕ ГЕОХИМИЧЕСКИЕ ВАРИАЦИИ}

\section{Ильченко В.Л. ${ }^{1}$, Сенчина Н.П. ${ }^{2}$}

${ }^{1}$ Геологический институт КНЦ РАН, Апатиты, vadim@geoksc.apatity.ru

${ }^{2}$ Санкт-Петербургский горный университет, Санкт-Петербург,

n_senchina@inbox.ru

\section{Аннотация}

На основе волновой геодинамики рассмотрена природа тектонических нарушений в породах древнего кристаллического фундамента - в связи с развитием рельефа и площадным распределением геохимических аномалий на поверхности. Результаты проведённого исследования показали возможную связь геоморфологических особенностей объекта с его геохимическими характеристиками (площадными вариациями концентраций химических элементов).

\section{Summary}

Nature of tectonic disturbances in the ancient crystalline basement rocks with comparison of the relief development and of the geochemical anomalies area distribution on the surface were considered on the basis of wave geodynamics. The study results show possible relationship of the object's geomorphological features and its geochemical characteristics (area variations of chemical elements concentrations).

\section{Введение}

Одним из важнейших методов поисковой геологии является геохимическая съёмка, позволяющая находить месторождения полезных ископаемых в 